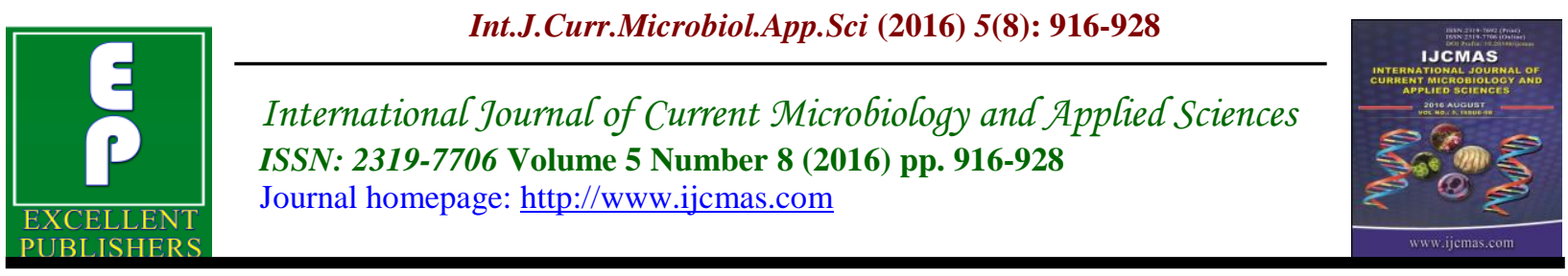

Original Research Article

http://dx.doi.org/10.20546/ijcmas.2016.508.103

\title{
Identification of Novel Chitinolytic Streptomyces. spp from a Sacred Grove and it's in vitro Antagonistic Activity Analysis
}

\author{
C. Asha Poorna* and N.S. Pradeep \\ Microbiology Division, Jawaharlal Nehru Tropical Botanic Garden Research Institute, \\ Palode, Thiruvanathapuram-695562, India \\ *Corresponding author
}

Keywords

Actinobacter, chitinase, antifungal, Streptomyces, Aspergillus niger

\section{Article Info}

Accepted:

18 July 2016

Available Online:

10 August 2016

\section{A B S T R A C T}

Fungal phytopathogen infection in cultivation of economically important crops is the major problem faced worldwide. Use of fungicide is causing deleterious effect to ecosystem including plants and humans. Currently scientists are searching for an alternative environment friendly technique to protect plants from fungal attack. The presences of chitin in the cell wall of fungus lead to the search of chitinase enzyme as potent bio-control agent. Chitinase help in the degradation of chitin to $\mathrm{N}$-acetyl glucosamine. In this paper we search for potent chitinolytic Actinobacters from soil collected from a sacred grove in Kerala. Among the fourteen isolates made, four exhibited chitinolytic activity. Molecular analysis technique together with traditional morphological and biochemical methods was used for the identification of strains and all strains identified as Streptomyces species of this two identified as potent fungal chitinase producers. The Streptomyces KAZ 180 observed to have antifungal activity against Aspergillus niger MTCC 1344 with chitinase activity of $2.48 \mu \mathrm{M} / \mathrm{ml}$ and Streptomyces $K A Z 312$ with $1.75 \mu \mathrm{M} / \mathrm{ml}$. Both the stain observed to have F-19 gene based on the primer designed from conserved regions of Fungal -19 chitinase gene of Streptomyces sp.

\section{Introduction}

Sacred groves are believed as patches of forest untouched by human for centuries and have high biodiversity, so these regions where of great interest of research. Actinomycetes (order Actinomycetales) are aerobic gram +ve bacteria with high GC content and characterized by the formation of aerial mycelium on solid media. Genus Streptomyces of genera Actinomycetes is of chemotaxonomy of many genera. They have a characteristic "earthy" odour due to the presence of geosim a low mol.wt. volatile compound. Now-a-days molecular screening using ribosomal DNA sequencing has been widely used in the identification of actinomycetes.

Chitin is the second most abundant homopolymer of $\beta$-1,4-linked $\mathrm{N}$ acetylglucosamine (NAG) with a critical biological role in our ecosystems. It is the major constituent of fungi and plant cell walls, exoskeleton of insect, krill, shellfish, and also the main constituent of cuticle of 
most insect peritrophic membrane that protect intestine of insects, the tracheal tubes, upper skin and muscles along with protein and lipids that protect them from attack (Brzeziska et al.,2014).Chitin is a major source of nutrient for many Streptomyces and they have developed complex extracellular systems for its utilization and degradation of it results in the releases substantial amounts of carbon and nitrogen nutrients. Still, its crystallized conformation and heterogenic chemical composition make chitin particularly recalcitrant to degradation. The functional property and physiological activity of chitin depends mostly on its chain length and molecular weight. Nearly all natural polysaccharides are neutral or acidic but chitin is basic(Senol et al., 2014).Two types of enzymes are involved in the hydrolysis of chitin viz: chitinase (E.C. 3.2.1.14) and $\beta-\mathrm{N}$ acetyl hexosaminidase (E.C.3.2.1.52). Chitinases are classified based on their depolymerization activity, including endochitinases (EC 3.2.1.14), which randomly cleave chitin molecules and exochitinases, like $\quad \beta$ - $\quad(1,4)-\mathrm{N}$ acetylglucosaminidases (EC 3.2.1.30) and 1,4- $\beta$-chitobiosidases (EC 3.2.1.29) that progressively degrade chitin from nonreduced ends.

F-19 chitinases of Streptomyces are of special interest because of their high levels of similarity to plant class IV chitinases andantifungal activity (Davies and Henrissat, 1995).N-acetyl- $\beta$-D- glucosamine (GlcNAc) is a good food additive and pharmacological agent and traditional process for making it is very costly and lead to acidic pollution, therefore identification of a novel chitinase producing strain in conversion of chitin to GlcNAc is of great worth. Based on amino acid sequence similarity chitinases belong to glycosyl hydrolases Family-18 and Family-19. A detail study of Streptomyces F-19 chitinases is critical, to elucidate why the distribution of F-19 chitinases in organisms is more restricted than that of $\mathrm{F}-18$ chitinases and how these types of chitinases developed.In this paper we discuss about novel isolates of Streptomyces from a sacred grove in south Kerala and its in-vitro antagonistic activity. The strains where identified by molecular screening of 16sDNA and the fungal chitinase (F-19) gene identified by using primer designed from the conserved region.

\section{Materials and Methods}

\section{Isolation of antagonistic strains}

Soil sample collected from (Kulathupuzha Sastha Temple reserve forest -2 acres). Surface soil with high humus content was removed up to $15 \mathrm{~cm}$ and samples were collected from different regions in sterile polythene bagsand kept at $4^{\circ} \mathrm{C}$ for further studies. Isolation of microorganism was done by serial dilution and platedon Glycerol asparagine agar and Starch Casein agar. Culture plates where stored at $28^{\circ} \mathrm{C}$ for 7 days. Morphologically different types of colonies were picked up separately.

\section{Preparation of Colloidal Chitin}

20.0 g commercial chitin was added into 400 $\mathrm{ml}$ of conc. $\mathrm{HCl}$. The mixture was stirred for $30 \mathrm{~min}$ and poured into $2 \mathrm{~L}$ ice cold distilled water. Then, the mixtures was left overnight at room temperature and filtered to separate colloidal chitin solution. The filtered colloidal chitin was washed for several times with distilled water to $\mathrm{pH}$ 6.5, autoclaved and stored at $4^{\circ} \mathrm{C}$.

\section{Primary Screening for Chitinase Activity}

The isolates were subjected to the primary screening for chitinolytic activities in 
minimal media with $0.1 \%$ colloidal chitin of composition: chitin (0.2\%), $\mathrm{MgSO}_{4} .7 \mathrm{H}_{2} \mathrm{O} \quad(0.5 \%), \mathrm{K}_{2} \mathrm{HPO}_{4} \quad(0.7 \%)$, $\mathrm{KH}_{2} \mathrm{PO}_{4}(0.3 \%), \quad \mathrm{FeSO}_{4} .7 \mathrm{H}_{2} \mathrm{O}(0.01 \%)$, $\mathrm{MnCl}_{2}(0.001 \%), \mathrm{NaCl}(0.03 \%)$, Yeast Extract $(0.02 \%)$ and agar $(2 \%)$.The plates were incubated at $28 \pm 1{ }^{\circ} \mathrm{C}$ for a period of 15 days. Plates stained with $0.2 \%$ Congo red solution and destained with $4 \mathrm{~N} \mathrm{NaCl}$ and zone measured. Based on the formation of zone diameter the 12 strains were grouped as weak $(+)$, moderate $(++)$, highly active $(+++)$.

\section{Secondary Screening for Chitinase Activity}

Secondary screening for chitinase production was done in minimal media of composition with colloidal chitin $(0.2 \%)$, $\mathrm{MgSO}_{4} .7 \mathrm{H}_{2} \mathrm{O}$ (0.5\%), $\mathrm{K}_{2} \mathrm{HPO}_{4} \quad(0.7 \%)$, $\mathrm{KH}_{2} \mathrm{PO}_{4}(0.3 \%), \quad \mathrm{FeSO}_{4} .7 \mathrm{H}_{2} \mathrm{O} \quad(0.01 \%)$, $\mathrm{MnCl}_{2}(0.001 \%), \mathrm{NaCl}(0.03 \%)$ and Yeast Extract $(0.02 \%)$. Preinoculum of $25 \mathrm{ml}$ was prepared and $5 \mathrm{ml}$ added to culture broth and incubated at $28^{\circ} \mathrm{C}$ for 7 days and sample where withdrawn at regular interval of $24 \mathrm{~h}$ and centrifuged at $10,000 \mathrm{rpm}$ for $10 \mathrm{~min}$ at $4^{\circ} \mathrm{C}$ and used as crude enzyme and total protein estimated by Bradford's method (1976).

\section{Chitinase Enzyme assay}

Chitinase activity was measured with $1 \%$ colloidal chitin in Phosphate buffer $(\mathrm{pH}$ 7.0) as substrate. The culture broth was centrifuged and crude enzyme solution 0.5 $\mathrm{ml}$ was added to $1.0 \mathrm{ml}$ of substrate solution. The mixture was incubated at $30^{\circ} \mathrm{C}$ for $45 \mathrm{~min}$ and the amount of reducing sugar produced in the supernatant was determined by DNS method(Miller 1959). One unit of chitinase activity was defined as the amount of enzyme that produced $1 \mu \mathrm{mol}$ of $\mathrm{N}$-acetyl glucosamine per min.

\section{Primary screening for Antifungal Activity}

Dual culture method was followed and selected strains cultured against standard fungal strains obtained from Microbial Type Culture Collection and Gene Bank (MTCC), Chandigarh. Actinomycetes strains and the fungal strains were grown on Sabouraud's agar for 5 days at $30^{\circ} \mathrm{C}$ separately. Mycelia discs of $6 \mathrm{~mm}$ diameter were punctured aseptically from these plates using cork borer and placed at a distance of $2.5 \mathrm{~cm}$ apart in fresh agar plates and incubated for 7 days at $28^{\circ} \mathrm{C}$, fresh plates with fungal discs alone served as control plates. The percentage of inhibition of growth of mycelia forming fungi were calculated by measuring the diameter of the fungal strains in dual culture plate with that in control plate, by applying the formula, $\%$ of inhibition $=\left(\mathrm{A}_{1}-\mathrm{A}_{2}\right) / \mathrm{A}_{1} \mathrm{X}$ 100 , where $A_{1}$ - diameter of fungal colony in control plate, $\mathrm{A}_{2}$ - diameter of fungal colony in dual culture plate(Roberts and Selitrenikoff, 1986).Based on the percentage of inhibition the strains were grouped into strong (>70\% inhibition), moderate (40-70\% inhibition), medium (20-40\%), Low activity $(<20 \%$ inhibition) and non-active (no inhibition).

\section{DNA extraction, sequencing and analysis}

Streptomyces isolates were cultured in YEME broth of composition (g/L) YE-3.0, malt extract 3.0, sucrose-340.0, glucose10.0 , peptone- 3.0 in $1000 \mathrm{ml}$ distilled water and $\mathrm{pH}-7.2$ supplemented with $5 \mathrm{mM}$ $\mathrm{MgCl}_{2}$, and $0.5 \%$ (w/v) glycine. The cultures are grown in YEME medium with shaking at $180 \mathrm{rpm}$ for 3 days at $28^{\circ} \mathrm{C}$ and DNA of antagonistic isolate was extracted(Murray and Thompson, 1980, Tripathi and Rawal 1998). Cultures centrifuged at $8000 \mathrm{rpm}$ for $10 \mathrm{~min}$ at $4^{\circ} \mathrm{C}$ and cell washed twice with TE buffer 
(10mM Tris/HCl and $1 \mathrm{mM} \mathrm{Na} \mathrm{NaDTA}_{2} \mathrm{pH}-8$ and $0.1 \mathrm{~g}$ mycelia suspended in $500 \mu \mathrm{l} \mathrm{TE}$ buffer and $10 \mu \mathrm{l}$ of lysozyme $(20 \mathrm{mg} / \mathrm{ml})$ was added and incubate at $30^{\circ} \mathrm{C}$ for $30 \mathrm{~min}$ for protoplast formation. $35 \mu \mathrm{l}$ of $10 \% \mathrm{SDS}$ was added to stop reaction and to this added $7 \mu 1$ proteinase $\mathrm{K}$ and $0.5 \mathrm{M}$ EDTA and incubate for $1 \mathrm{~h}$ at $37^{\circ} \mathrm{C}$. Lysate extracted with equal volume of phenol/chloroform/isoamyl alcohol $(25: 24: 1 \quad \mathrm{v} / \mathrm{v})$, centrifuged at $12,000 \mathrm{xg}$ for $10 \mathrm{~min}$ and the aqueous phase was finally extracted with chloroform/isoamyl alcohol $(24: 1 \mathrm{v} / \mathrm{v})$ and transferred to fresh tubes. Double the volume of ice cold ethanol or single volume of propan-2-ol was added with $4 \mathrm{M} \mathrm{NaCl}$ and kept overnight. DNA coiled out and centrifuged at $12,000 \mathrm{xg}$ for $10 \mathrm{~min}$ at $4^{\circ} \mathrm{C}$, pellet was washed twice with $70 \%$ ethanol and air dried pellet was dissolved in $100 \mathrm{ml}$ of TE buffer. $10 \mu \mathrm{l}$ RNAase $(50 \mathrm{mg} / \mathrm{ml})$ was added and the mixture and incubated at $37^{\circ} \mathrm{Cfor} 2 \mathrm{~h}$ to remove RNA. The sample was again extracted with phenol as describedabove.

The PCR amplification for 16sRNA was done using two universal primers 8-27F 5'AGAGTTTGATCCTGGCTCAG-3' and 1495R, 5'-CTACGGCTACCTTGTTAC GA-3'. The reaction mix composed of $1 \mu \mathrm{l}$ of template DNA, $12.5 \mu$ l of emerald mix (Clontech laboratories), $9.5 \mu 1$ of nuclease free water, and $1 \mu \mathrm{l}$ each of forward and reverse primer. The PCR program was as follows, initial denaturation at $94^{\circ} \mathrm{C}$ for $3 \mathrm{~min}$, (1cycle), denaturation at $94^{\circ} \mathrm{C}$ for $30 \mathrm{sec}$, annealing at $58^{\circ} \mathrm{C}$ for $45 \mathrm{sec}$, extension $72^{\circ} \mathrm{C}$ for $7 \mathrm{~min} 35$ cycles and the cooling final extension at $72^{\circ} \mathrm{C}$ for $10 \mathrm{~min}$. The PCR product was purified as recommended by the manufacturer and then sequenced. These fragments were sequenced in both directions and sequencing was done at SciGenom labs, Kochi.Clustal-W software is used for the alignment of sequence (Thompson et al., 1997). MEGA-4 software used for sequence divergences analysis and was computed according to Kimura's two parameter model, in term of the number of nucleotide difference per site between pairs of sequence(Kimura, 1980)and in the pairwise sequence comparison the idles were excluded. Neighbor- joining (NJ) method was used for the analysis of the distance matrix for all pair-wise sequence combinations(Saitou and Nei, 1987). Phylogenetic tree constructed using MEGA-4 software with 1000 bootstrap replicates.

\section{Molecular screening of family chitinase-producing Streptomyces}

Oligonucleotide primers were prepared related to the conserved regions among the family 19 chitinase gene of Streptomyces sp. and the primers wereF19-F-5'-GCCTTCC TCGCCAACGTC-3' and F19-R-5'-CCGAG GATCTGGGTGTT-3'. A standard PCR was performed in a total volume of $25 \mu 1$, containing $12.5 \mu \mathrm{l}$ of emerald mix, $9.5 \mu \mathrm{l}$ of nuclease free water, $1 \mu 1$ of template DNA of Streptomyces sp. and $1 \mu \mathrm{l}$ each of forward and reverse primers. PCR utilized melting $94^{\circ} \mathrm{C}$ for $3 \mathrm{~min}$, and then 35 cycles of $94^{\circ} \mathrm{C}$ $30 \mathrm{sec}, 55^{\circ} \mathrm{C}$ for $1 \mathrm{~min} .30 \mathrm{sec}$, extension $72^{\circ} \mathrm{C}$ for $7 \mathrm{~min}$ and final extension at $72^{\circ} \mathrm{C} 7 \mathrm{~min}$. Purified PCR product were separated in $1.2 \%$ agarose gel and visualized by UVtransellimination.

\section{Results and Discussion}

Soil samples collected from sacred grove was enriched with calcium carbonate treatment and serial dilution was done. Plates incubated for 7 days and from this about 14 isolates were purified. Purified isolates were subjected to primary screening for chitinase activity on chitin agar plates with colloidal chitin as a sole carbon and energy source. The chitin degrading organism formed colonies of 1-4.4 $\mathrm{mm}$ in 
diameter, surrounded by clear zones indicating activity (Table 1 and Figure 1). Based on the cultural, morphological and biochemical characteristics the identification and taxonomic classification of Streptomyces was done. Morphological and cultural characterizations of four chitinolytic active isolates from Kulthupuzha region were studied on four different ISP media (ISP-2, ISP-3, ISP-4, and ISP-5) (results not shown). The colors of aerial mycelium, reverse side of the colony, soluble pigment and growth density are detected. It was observed that all four selected isolates has exhibited growth in all tested media, but at different growth densities. Certain Streptomyces isolates exhibited good growth and some moderate growth on the four tested media. The abundance and the color of the mycelium depended on the medium composition and the age of the culture. It was noted that the color differed significantly for all isolated strains when ISP-2, 4, or5 were used. But, few differences were observed when ISP-3 medium was used(results not shown).

Dual plate assay against MTCC 1344 (Aspergillus niger) a soil borne phytopathogens and selected Streptomyces spp and the plates were incubated for 4 days for growth and anti-fungal activity explained in Table. 2. Antagonistic phenomena against fungi can be explained by several mechanisms, including antibiosis and parasitism.

In this study out of the 14 isolates, 4 actinobacteria showed clear zone on chitin agar plates and these strains were subjected to secondary production. Chitinase production was performed in $1 \%$ colloidal chitin medium, total protein and chitinase activity estimated. The selected StreptomycesKAZ 180 has shown highest chitinase activity related to other strains (Figure. 2) followed by Streptomyces $K A Z$
312 (Figure. 3) compared to Streptomyces KAZ311and StreptomycesKAZ360 (Figure. 4 and 5).

The molecular methods are more rapid and arebased on phenotypic characteristics. The rRNA gene is the most conserved (least variable) DNA in all cells. Portions of the rDNA sequence from distantly related organisms are remarkably similar. This means that sequences from distantly related organisms can be precisely aligned, making the true differences easy to measure. For this reason, genes that encode the rRNA (rDNA) have been used extensively to determine taxonomy, phylogeny (evolutionary relationships), and to estimate rates of species divergence among microbes. Thus the comparison of 16SrDNA sequence can show evolutionary relatedness among microorganisms. Four cultures with chitinase activity where subjected to DNA extraction and PCR amplification for 16SrDNA. The sequence was blasted in NCBI BLAST, strains showing similarity was taken for phylogenic tree construction in MEGA-4 software (Figure.6, 7, 8, and 9).Blast analysis of sequence in NCBI was done and evolutionary tree constructed using selected sequence which has shown similarity of about $90 \%$ in MEGA4 software, Streptomyces KAZ 180 has 36\% similarity to species Streptomyces zaomyceticus. Streptomyces KAZ -360 have similarity to Streptomyces strain and only three strains observed to have similar sequence related to strain 360 in NCBI. Streptomyces $K A Z-311$ - $62 \%$ similarity to Streptomyces bacterium and Streptomyces $K A Z-312$ with $65 \%$ similarity to Streptomyces.

The DNA of four selected cultures with chitinase activity was subjected to PCRamplification for F-19 chitinase gene using PCR-primers targeting the region of the catalytic domain of F- 19 chitinase genes ( 5 
bp). Two strains (KAZ-180, 312) observed to amplification and these amplicons were sequenced. Sequence analyzed in NCBI and similar strains with F-19 chitinase genes selected and phylogenic tree constructed (Figure. 10). The evolutionary history was inferred using the Neighbor-Joining method(Saitou and Nei, 1987). The bootstrap consensus tree inferred from 1000 replicates is taken to represent the evolutionary history of the taxa analyzed. Branches corresponding to partitions reproduced in less than 50\% bootstrap replicates are collapsed.

The percentage of replicate trees in which the associated taxa clustered together in the bootstrap test (1000 replicates) is shown next to the branches (Felsenstein, 1985). The evolutionary distances were computed using the Kimura 2-parameter method(Kimura, 1980) and are in the units of the number of base substitutions per site. Codon positions included were 1 st $+2 \mathrm{nd}+3 \mathrm{rd}+$ Noncoding. All positions containing gaps and missing data were eliminated from the dataset (Complete deletion option). There were a total of 174 positions in the final dataset for StreptomycesKAZ 180 and 219 positions in the final dataset for StreptomycesKAZ 312. Phylogenetic analyses were conducted in MEGA4(Tamura, et al.,2007).

In Actinomycetales order Streptomyces genus contains the largest number of species. Taxonomic status and phylogenetic analysis of Streptomyces have been based on a polyphasic approach including description and analysis of pigmentation, morphology, biochemical, and physiological properties (Shirling and Gottlieb, 1966, Anderson et al., 2001). More recently, molecularbiological techniques have been utilized for refining or extending classifications, especially those techniques targeting $16 \mathrm{~S}$ rRNA genomic regions (Gherbawy et al., 2012).

Table.1 Primary Screening of isolates from Kulathupuzha for Chitinase, production

\begin{tabular}{|l|l|l|}
\hline S.No. & Culture Name & Chitinase \\
\hline 1 & Streptomyces $K A Z 360$ & $3.2 \mathrm{~mm}$ \\
\hline 2 & Streptomyces $K A Z 311$ & $3.5 \mathrm{~mm}$ \\
\hline 3 & Streptomyces $K A Z 180$ & $4.4 \mathrm{~mm}$ \\
\hline 4 & Streptomyces $K A Z 312$ & $4.2 \mathrm{~mm}$ \\
\hline
\end{tabular}

Table.2 In vitro antagonism against Phytopathogens (MTCC-1344)after 3 days of growth

\begin{tabular}{|l|l|l|}
\hline S.No. & Culture Code & Inhibition (\%) \\
\hline 1 & Streptomyces $K A Z 360$ & $5.5 \%$ \\
\hline 3 & Streptomyces $K A Z 311$ & $4.3 \%$ \\
\hline 4 & Streptomyces $K A Z 180$ & $18.3 \%$ \\
\hline 5 & Streptomyces $K A Z 312$ & $12.2 \%$ \\
\hline
\end{tabular}


Fig.1 Extracellular chitinolytic activity of the Streptomyces isolates, on $0.2 \%$ colloidal chitin agar plates. Streptomyces.spp A- KAZ 180, B- KAZ360, C-KAZ-311, D -KAZ312
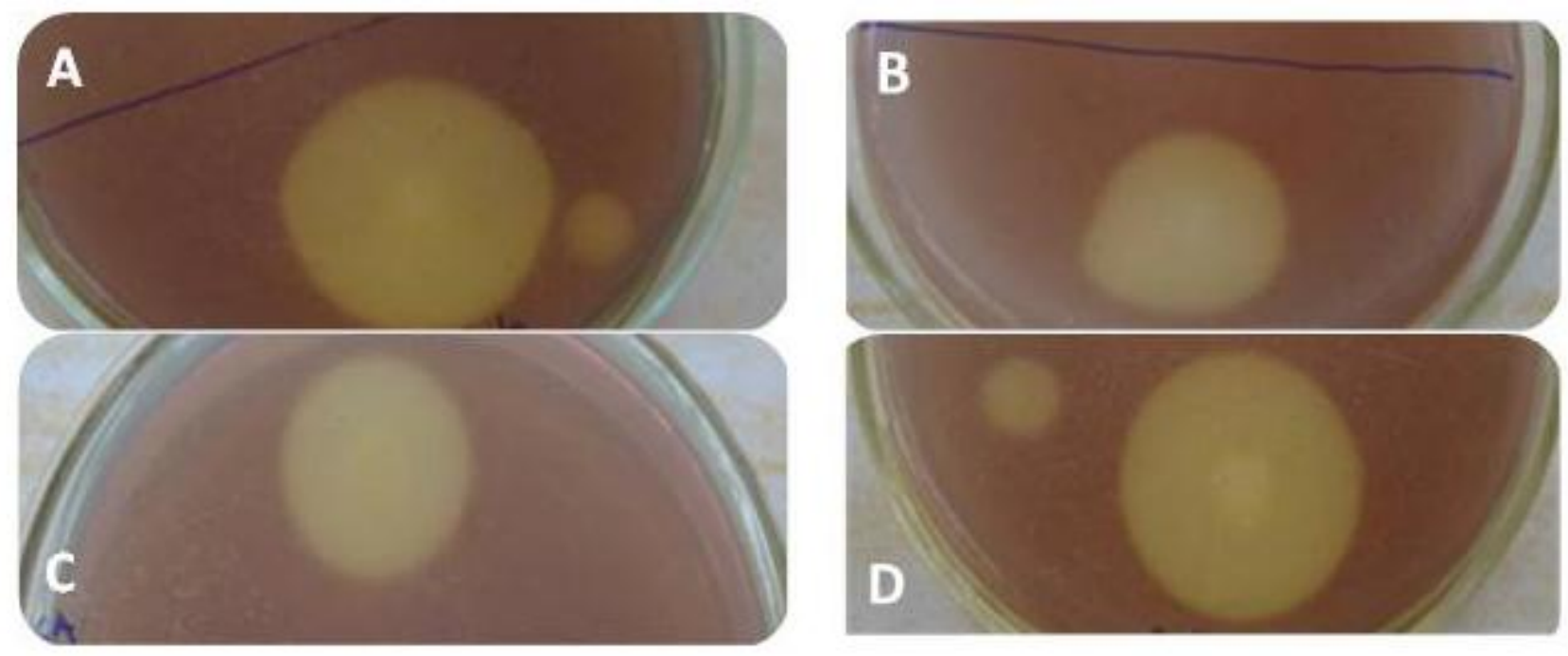

Fig.2 Chitinase production of selected strains Streptomyces KAZ-180 on colloidal chitin medium

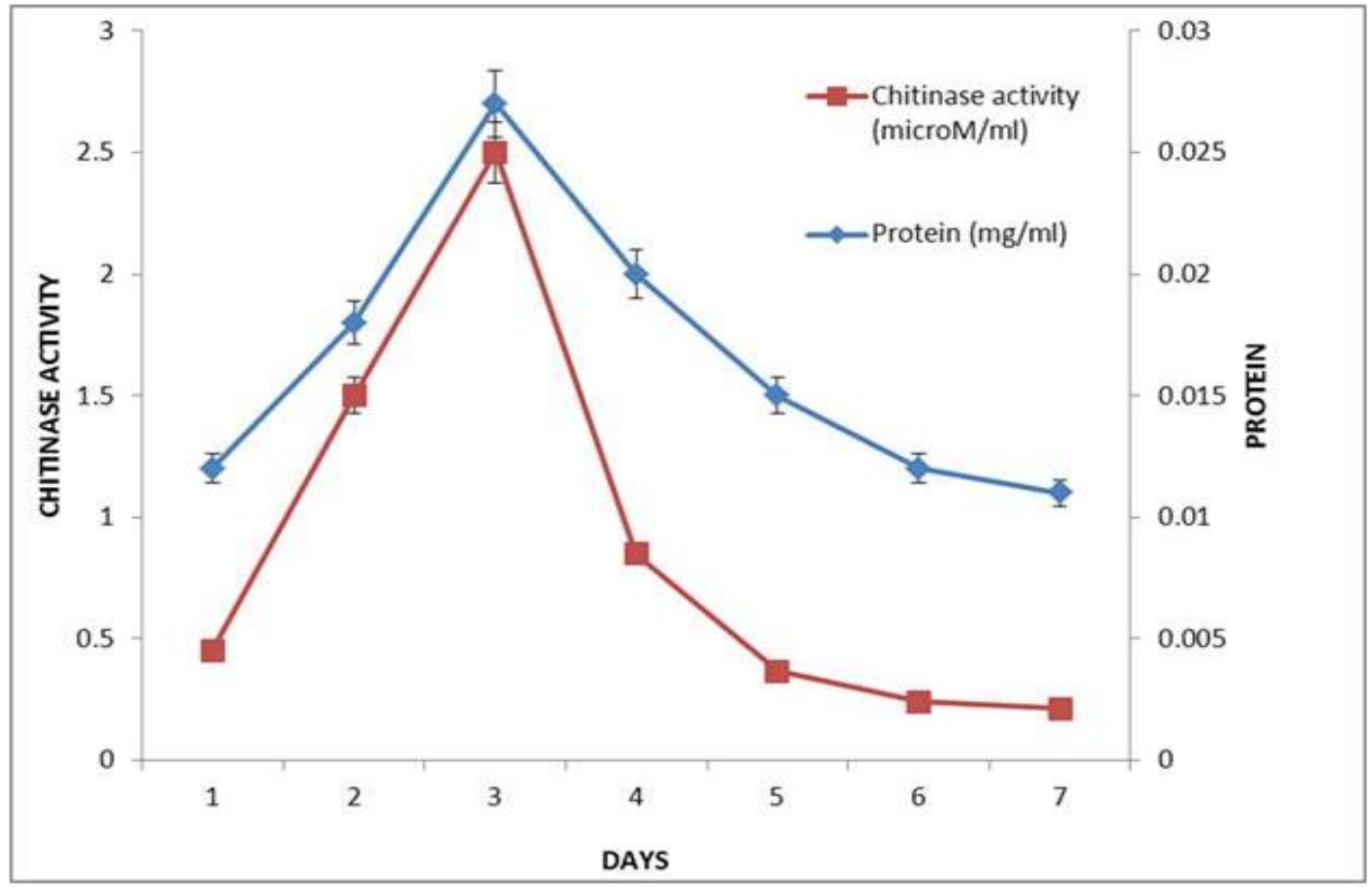


Fig.3 Chitinase production of selected strains Streptomyces KAZ-312 on colloidal chitin medium

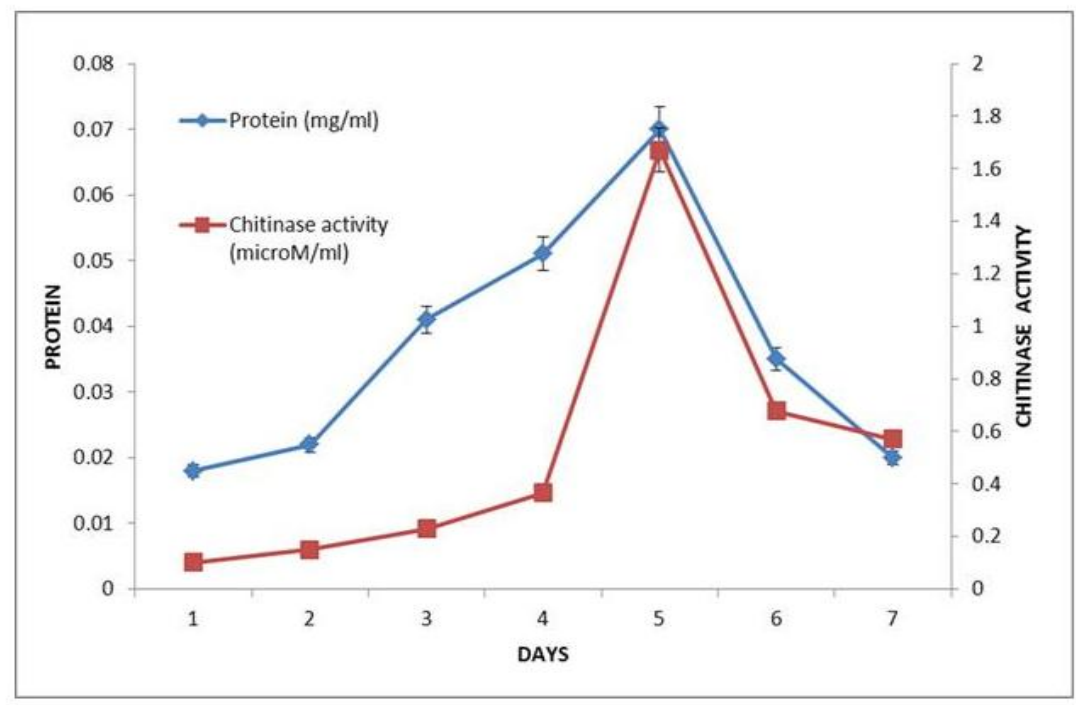

Fig.4 Chitinase production of selected strains Streptomyces KAZ 311 on colloidal chitin medium

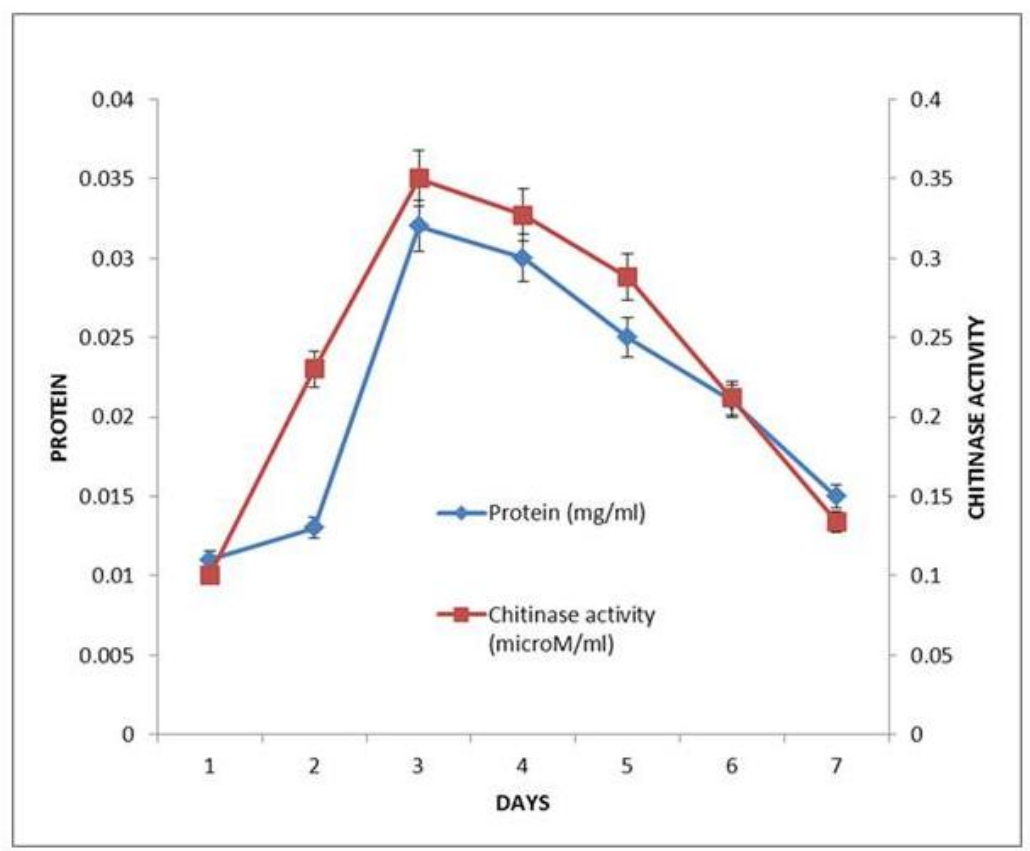


Fig.5 Chitinase production of selected strains Streptomyces KAZ360 on colloidal chitin medium

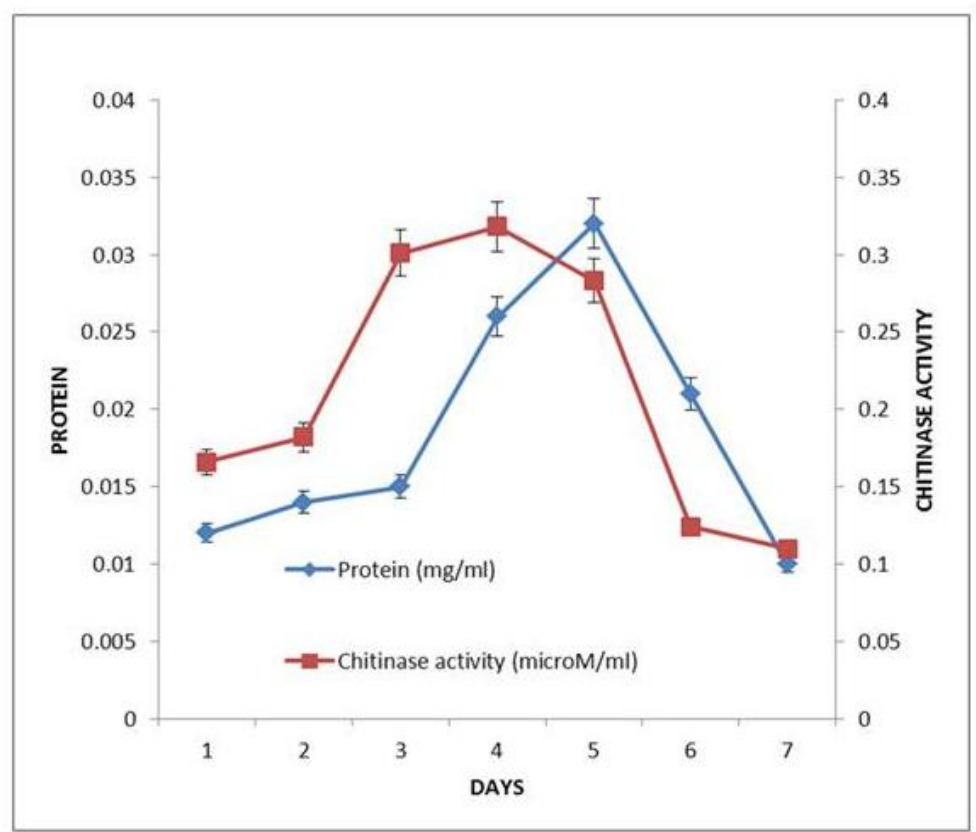

Fig.6 Streptomyces KAZ -180 isolated from Kulathpuzha observed to have $36 \%$ similarity to Streptomyces zaomyceticus strain
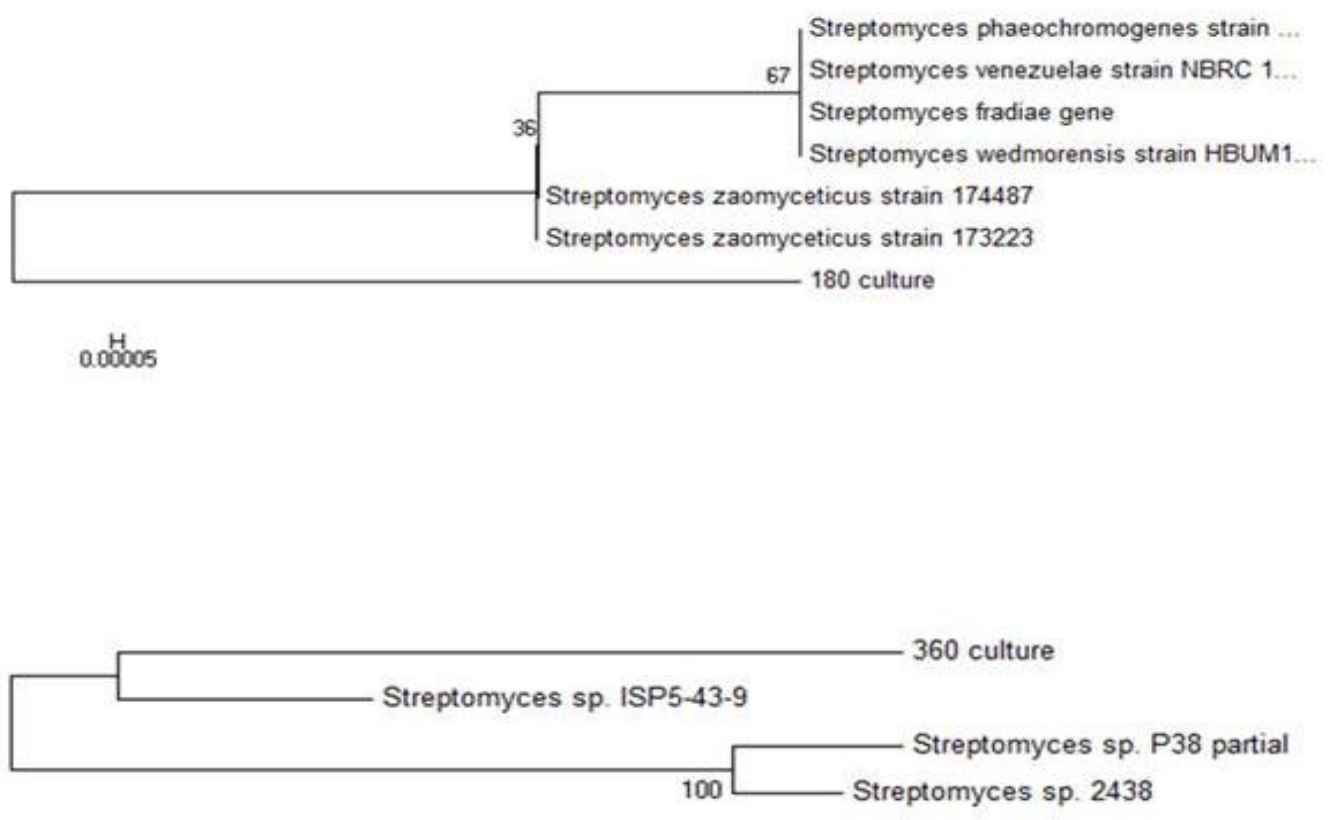
Fig.7 Streptomyces KAZ -360 isolated from Kulathpuzha observed to have similarity to Streptomyces strain. Only three strains have been observed to have similar sequence related to strain 360 in NCBI

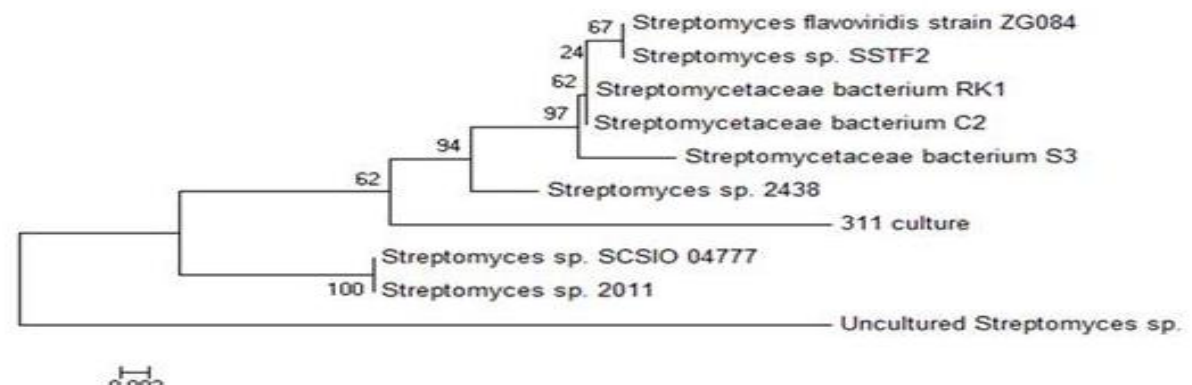

$\stackrel{2002}{0.02}$

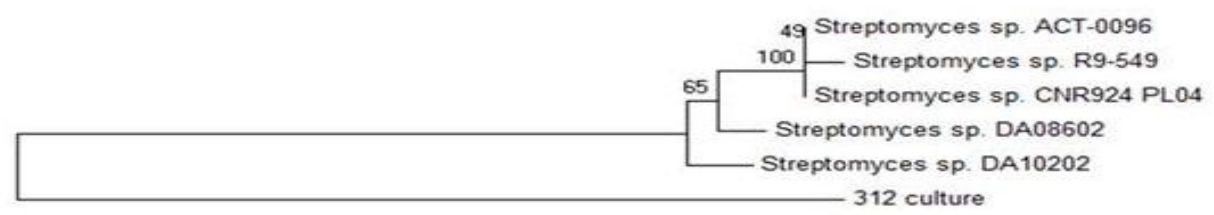

5.002

Fig.8 Streptomyces KAZ -311 isolated from Kulathpuzha observed to have $62 \%$ similarity to Streptomyces bacterium strain

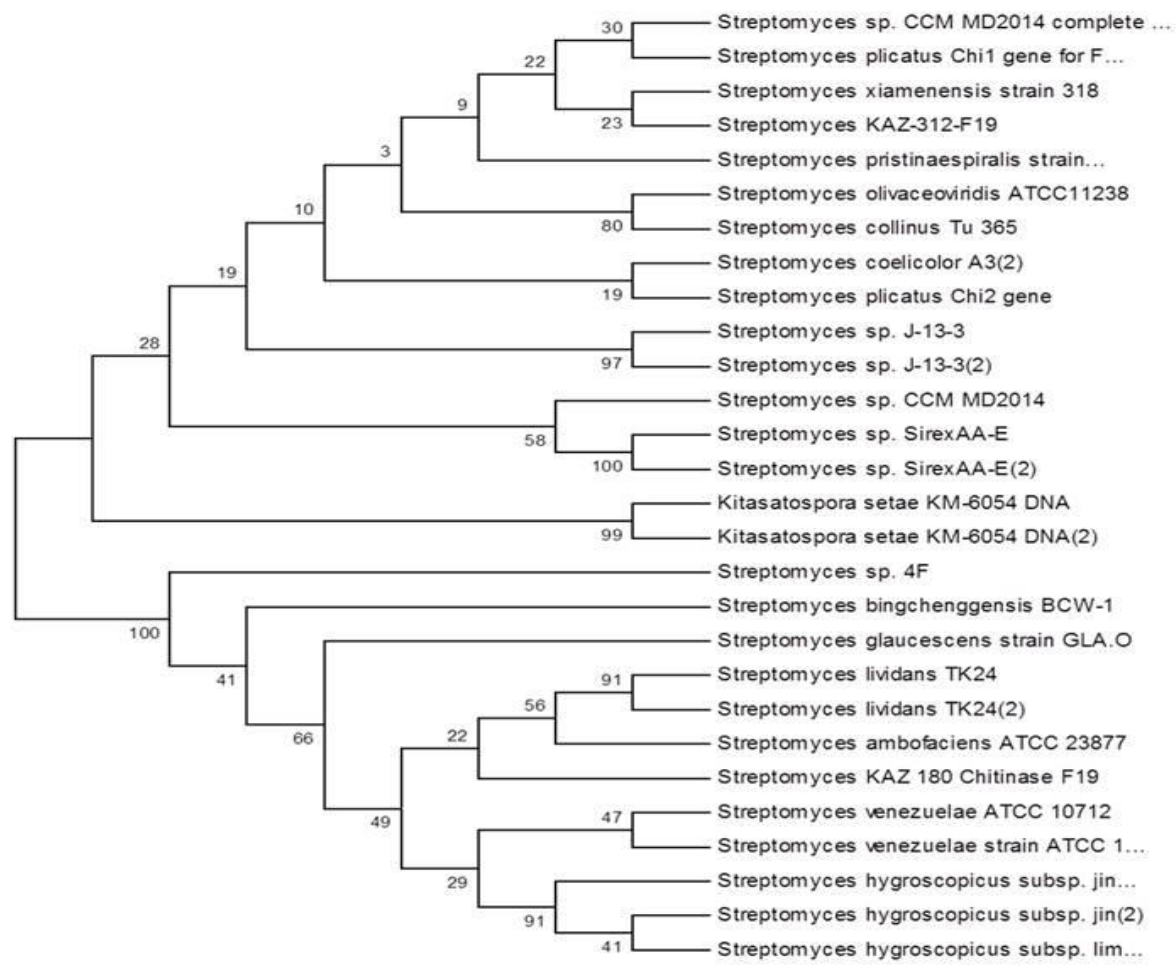


16SrRNA gene has become an important tool in bacterial identification since it provides information about the phylogenetic placement of species(Brenner et al., 2001). Primers are designed based on conserved regions. Conserved region carried more information about phylogenesis at the higher taxonomic levels, since they have evolved slowly and are highly similar among the different taxa whereas the variable regions have undergone more mutation during evolution and are more useful for classification at inter specific level. ChiHoang et al.,(2011) reported the identification of actinomycetes isolated from the sediment of the Tou-Chien River, Taiwan following Bergey's Manual of Determinative Bacteriology(Williams et al., 1989).The molecular method using 16SrRNA gene sequencing is rapid and convenient method than traditional methods and it's is recommended as an alternative approach for identification of Streptomyces (Park et al., 2006).The cumulative results from a limited number of studies to data suggest that 16SrRNA gene sequence provides genus level identification in most cases $(>90 \%)$ but less so with regard to species $(65-83 \%)$ about $1-14 \%$ of the isolates remain unidentified (Mignard and Flandrois 2006).

In some cases, hydrolytic enzymes such as chitinase, and other enzymes such as glucanases or proteases, may act against the fungal cell wall, antibiotic production also being probably involved. Streptomyces PTK-19 chitinase reported to have lysed cell wall of Fusarium oxysporum PTK2 (Thiagarajan et al., 2011). Chitinolytic systems of Streptomyces are usually composed of a diversity of enzymes with different specificities and chitinase from microorganisms are extremely important for the degradation and recycling of the carbon and nitrogen. Streptomyces rimosus identified based on 16SrRNA and chitinase has a molecular mass of $63 \mathrm{kDa}$ active at $\mathrm{pH}-$ 7 at $40-45^{\circ} \mathrm{C}$, which inhibited the growth of phytopathogen Fusarium solani and Alternaria alternate (Brzezinska et al., 2013). Streptomyces sp.PTK19 has reported to have $31.26 \mathrm{U} / \mathrm{ml}$ with optimum $\mathrm{pH} 5.5$ and $40^{\circ} \mathrm{C}$ with a stability at $30-45^{\circ} \mathrm{C}$ and has shown antagonestic activity against Fusarium oxysporum PTK2 (Thiagarajan et al., 2011). The nucleotide sequence from Streptomyces rimosus, the amplified gene fragment proved to be similar to the sequence of chitinase-encoding genes of the glycoside hydrolases family 18 (Brzezinska et al., 2013). There were similar reports related to family 19 chitinase identified using Southern hybridization with DIGlabeled chitinase probe showed that fragments around $23 \mathrm{~kb}, 10 \mathrm{~kb}, 5 \mathrm{~kb}$ and $3 \mathrm{~kb}$ in a partially digested chromosomal DNA of BRI 13 with BamHI harbored the chitinase gene. Fragments around $5 \mathrm{~kb}$ and $3 \mathrm{~kb}$ were cloned with pUC19 (Wong et al., 2013). Chtinilytic actinomycetes Streptomyces vinceusdrappus S5MW2 from Chilika Lake has shown antifungal activity against sclerotia producing pathogen Rhizoctonia solani (Yandigeri et al., 2015).

In conclusion, Streptomyces are thought to be one of the major chitinivorous microbial groups in soil due to their ability to degrade chitin. This has long been regarded as a characteristic feature of a soil Streptomyces. The multiplicity of chitinases in Streptomyces is due in part to the posttranslational proteolytic cleavage of the primary gene product and secondly to the existence of multiple chitinase genes in many Streptomyces. The present work aimed for the isolation of chitinolytic actinomyctes from soil of a sacred grove near Kulathupuzha. Also the work focuses on the morphological characterization and genomic DNA isolation and its 16SrDNA 
amplification. In the present study 14 isolates where purified from the soil sample of which four strains have shown chitinase activity and the genomic DNA isolation was performed together with identifying two strains possessing fungal chitin (F-19) gene. Both the Streptomyces spp. observed to be a promising producer of chitinolytic enzyme and antimicrobial activity. Therefore, the present study demonstrated that Streptomyces KAZ 180 and KAZ312 as novel potential sources as biocontrol agent at least against the pathogenic fungus Aspergillus niger.

\section{Acknowledgement}

The authors are grateful to Director, JNTBGRI, for providing facilities to carry out the research work. Asha Poorna.C is grateful to SERB -DST for financial support to carry out this work as part of her Fast track young scientist fellowship scheme.

\section{References}

Anderson, SA, Wellington. EMH. 2001; The taxonomy of Streptomyces and related genera, Inter. J Sys. Evo. Microbiol, 51, 797-814.

Bradford MM, 1976; A rapid and sensitive method for the quantitation of microgram quantities of protein utilizing the principle of protein-dye binding. Anal. Biochem. 72, 248-254.

Brzezinska MS, Jankiewicz U, Burkowska A, Walczak M, 2014; Chitinolytic microorganisms and their possible application in environmental protection, Cur. Microbiol, 68: 71-81

Brzezinska MS, Jankiewicz U, Walczak M, 2013; Biodegradation of chitinous substances and chitinase production by the soil actinomycete Streptomyces rimosus. Inter. Biodete. Biodegr 84, 104-110.

Chi Hoang, K, Lai T-H, ShengLin C, Chen
Ying Tsong and Liau C,Y. 2011, The Chitinolytic Activities of Streptomyces sp. TH-11, Int J Mol Sci. 2011; 12(1): 56-65.

Davies G, Henrissat B, 1995; Structures and mechanisms of glycosyl hydrolases. Stru. 3, 853-859.

Felsenstein J. 1985; Confidence limits on phylogenies: An approach using the bootstrap. Evol. 39:783-791.

Gherbawy Y, Elhariry H, Altalhi A, El-Deeb B, Khiralla G, 2012; Molecular screening of Streptomyces isolates for antifungal activity and Family 19 Chitinase enzymes,J Microbiol, Vol. 50, No. 3, pp. 459-468.

Janda M. J, and Abbott, S.L, 16S rRNA Gene Sequencing for Bacterial Identification in the Diagnostic Laboratory: Pluses, Perils, and Pitfalls, J Clin Microbiol. 2007 Sep; 45(9): 2761-764.

Kimura M, 1980; A simple method for estimating evolutionary rate of base substitutions through comparative studies of nucleotide sequences. $J$. Mole. Evol. 16:111-120.

Mignard, S and Flandrois, J.P. 2006, 16S rRNA sequencing in routine bacterial identification: a 30-month experiment. J Microbiol Methods. 2006 Dec; 67(3):574-81. Epub 2006 Jul 21.

Miller GL, 1959; Use of dinitrosalicylic acid reagent for determination of reducing sugars. Anal. Chem. 31, 426-428.

Murray MG, Thompson WF, 1980; Rapid isolation of high molecular weight plant DNA. Nucl. Aci. Res. 8: 43214325.

Park HS, John J, Kilbane II, 2006; Rapid detection and high-resolution discrimination of the genus Streptomyces based on $16 \mathrm{~S}$ rRNA spacer region and denaturing gradient gel electrophoresis. J. Ind. Microbiol. Biotechnol. 33, 289-297. 
Roberts, Selitrenikoff, 1986; Isolation and partial characterization of two antifungal proteins from barley. Biochem Biophys Acta. 880:161-170.

Saitou N, Nei M. 1987; The neighborjoining method: A new method for reconstructing phylogenetic trees. Mol. Biol Evol. 4:406-425.

Senol M, Nadaroglu. H, Dikbas. N, Kotan R., 2014; Purification of Chitinase enzymes from Bacillus subtilis bacteria TV-125, investigation of kinetic properties and antifungal activity against Fusarium culmorum, Annals of Clinical Microbiology and Antimicrobials. 13:35.

Shirling EB, Gottlieb D, 1966; Methods for characterization of Streptomyces species. Inst. J. Syst. Bacteriol. 16, 313-340.

Tamura K, Dudley J, Nei M, Kumar S, 2007; MEGA4: Molecular Evolutionary Genetics Analysis (MEGA) software version 4.0. Mol. Biol. Evol. 24:1596-1599.

Thiagarajan V, Revathia R, Aparanjinib K, Sivamanic P, Girilala M, Priyad CS, Kalaichelvana PT. 2011; Extra cellular chitinase production by Streptomyces sp. PTK19 in submerged fermentation and its lytic activity on Fusarium oxysporum PTK2 cell wall. Int J Curr
Sci, 1: 30-44.

Thompson JD, Gibson TJ, Plewniak F, Jeanmougin F, Higgins DG. 1997; The Clustal X windows interface: flexible strategies for multiple sequence alignment aided by quality analysis tools. Nuc. Aci. Res. 24, 4876-4882.

Tripathi G, Rawal SK, 1998; Simple and efficient protocol for isolation of high molecular weight DNA from Streptomyces aureofaciens. Biotechnol. Tech. 12, 629-631.

Williams ST, Sharpe ME, Holt JG, 1989; Bergey's manual of systematic bacteriology, vol. 4. Williams and Wilkins, Baltimore, MD.

Wong Ng WM, Anton CMVL, Ampon KA, and Lee PC, 2013; Isolation and Characterization of Soil Chitinolytic Bacteria.

Yandigeri MS, Malviya N, Solanki MK., Shrivastava P, Sivakumar G., 2015, Chitinolytic Streptomyces vinaceusdrappus S5MW2 isolated from Chilika lake, India enhances plant growth and biocontrol efficacy through chitin supplementation against Rhizoctonia solani. World J Microbial Biotechnology. 31(8):1217-25. doi: 10.1007/s11274-015-1870-x.

\section{How to cite this article:}

Asha Poorna, C., and Pradeep, N.S. 2016. Identification of Novel Chitinolytic Streptomyces. spp from a Sacred Grove and it's in vitro Antagonistic Activity Analysis. Int.J.Curr.Microbiol.App.Sci. 5(8): 916-928. doi: http://dx.doi.org/10.20546/ijcmas.2016.508.103 